\title{
Monitoring survival of Lactobacillus casei ATCC 393 in probiotic yogurts using an efficient molecular tool
}

\author{
Marianthi Sidira, ${ }^{*} \dagger$ Georgia Saxami, ${ }^{*}$ Dimitra Dimitrellou, ${ }^{*}$ Valentini Santarmaki, ${ }^{*}$ Alex Galanis, ${ }^{*}$ \\ and Yiannis Kourkoutas*1 \\ *Applied Microbiology and Molecular Biotechnology Research Group, Department of Molecular Biology and Genetics, \\ Democritus University of Thrace, Alexandroupolis, 68100, Greece \\ †Food Biotechnology Group, Section of Analytical Environmental and Applied Chemistry, Department of Chemistry, \\ University of Patras, GR-26500 Patras, Greece
}

\section{ABSTRACT}

The aim of the present study was to monitor the survival of the probiotic strain Lactobacillus casei ATCC 393 during refrigerated storage of natural regular yogurts compared with Lactobacillus delbrueckii ssp. bulgaricus. Both free and immobilized cells on supports of high industrial interest, such as fruits and oat pieces, were tested. Microbiological and strain-specific multiplex PCR analysis showed that both free and immobilized $L b$. casei ATCC 393 were detected in the novel products at levels required to confer a probiotic effect (at least $6 \log \mathrm{cfu} / \mathrm{g}$ ) for longer periods than required by the dairy industry $(\geq 30 \mathrm{~d})$ during storage at $4^{\circ} \mathrm{C}$. In contrast, the viable bacterial density of $L b$. delbrueckii ssp. bulgaricus decreased to levels $<6$ log cfu/g after 14 $\mathrm{d}$ of cold storage. Of note, the final $\mathrm{pH}$ of all products was 4.2 to 4.3 . Acid resistance or cold tolerance of $L b$. casei ATCC 393 apparently allows for increased survival compared with $L b$. delbrueckii ssp. bulgaricus in these yogurt formulations.

Key words: multiplex PCR, Lactobacillus delbrueckii ssp. bulgaricus, fruit, oat

\section{INTRODUCTION}

Currently, interest is increasing in developing novel foods containing probiotic microorganisms, such as bifidobacteria and lactic acid bacteria (LAB). Such functional foods demonstrate great potential in promoting human health. Maintenance of intestinal microbial homeostasis, prevention of pathogenic infections, stabilization of the gastrointestinal (GI) barrier function, and production of anticancer and antimutagenic compounds (Choi et al., 2006; Boirivant and Strober, 2007; Saulnier et al., 2009) are included among the beneficial effects of probiotic-based foods, mainly yogurt

Received November 4, 2012

Accepted January 19, 2013.

${ }^{1}$ Corresponding author: ikourkou@mbg.duth.gr and other dairy products. Thus, a probiotic-rich diet is linked to the prevention and potential treatment of several severe digestive disorders, such as inflammatory bowel disease (Boirivant and Strober, 2007) and colorectal cancer (Fotiadis et al., 2008).

To deliver health benefits, probiotic products need to contain an adequate amount of live bacteria (at least $10^{6}$ to $10^{7} \mathrm{cfu} / \mathrm{g}$; Oliveira et al., 2002; Boylston et al., 2004) able to survive the acidic conditions of the upper GI tract and proliferate in the intestine, a requirement that is not always fulfilled (Vinderola et al., 2002; Boylston et al., 2004). In general, the food industry has adopted the recommended level of $10^{6}$ $\mathrm{cfu} / \mathrm{g}$ of probiotic bacteria at the time of consumption. Thus, a daily intake of at least $10^{8}$ to $10^{9}$ viable cells, which could be achieved by consumption of at least $100 \mathrm{~g}$ of probiotic food, has been suggested as the minimum intake to provide a probiotic effect (Boylston et al., 2004). However, monitoring the survival of the probiotic cultures in foods is hampered by the lack of accurate, reliable, convenient, and sensitive methods of identification, with the ability to distinguish the strains of interest among other closely related microorganisms present in the products.

It has been established that cell immobilization enhances the viability of cultures (Mattila-Sandholm et al., 2002; Kourkoutas et al., 2005, 2006), probably because of the protective microenvironment formed. Many studies have focused on immobilization of probiotic bacteria in various supports, such as starch (MattilaSandholm et al., 2002), fruit pieces (Kourkoutas et al., 2005, 2006; Kopsahelis et al., 2007), casein (Dimitrellou et al., 2008, 2009), and wheat grains (Bosnea et al., 2009). These efforts were aimed at stabilization of cells and formulation of new types of foods fortified with immobilized health-promoting bacteria that are only released upon reaching the human gut. Cereals, such as oat pieces, as well as fruits, are expected to deliver the immobilized probiotic LAB to the human gut when used as immobilization supports (Chen et al., 2005). In addition, because they contain potential prebiotic com- 
pounds, their potential functional properties should be explored (Charalampopoulos et al., 2003).

Among LAB, Lactobacillus casei ATCC 393 has been extensively incorporated into food products to confer probiotic properties (Kourkoutas et al., 2005, 2006; Li et al., 2009), and Lactobacillus delbrueckii ssp. bulgaricus is widely used in yogurt production. Recently, new methods based on multiplex PCR for rapid detection and identification of Lb. casei ATCC 393 and Lb. delbrueckii ssp. bulgaricus in food products have been demonstrated (Karapetsas et al., 2010; Nikolaou et al., 2011).

Hence, the aim of the present study was to monitor the survival of the probiotic strain $L b$. casei ATCC 393 during refrigerated storage of yogurts compared with Lb. delbrueckii ssp. bulgaricus, which is widely used in production of commercial yogurts. Both free and immobilized cells on supports of high industrial interest, such as fruits and oat pieces, were tested. Maintenance of probiotic cell viability is the most important factor in the characterization of a product as probiotic.

\section{MATERIALS AND METHODS}

\section{Starter and Probiotic Cultures}

Probiotic cultures of Lb. casei ATCC 393 (DSMZ, Braunschweig, Germany) and Lb. delbrueckii ssp. bulgaricus LB-12 (Chr. Hansen, Athens, Greece) were grown at $37^{\circ} \mathrm{C}$ for $72 \mathrm{~h}$ on de Man, Rogosa, and Sharpe (MRS) broth (Fluka, Buchs, Switzerland). Pressed wet weight cells $(\sim 0.5-1.0 \mathrm{~g}$ of dry weight) were prepared and used directly for cell immobilization and production of probiotic yogurt. A starter culture of Streptococcus salivarius ssp. thermophilus (Chr. Hansen) was grown at $37^{\circ} \mathrm{C}$ for $24 \mathrm{~h}$ in pasteurized milk.

\section{Cell Immobilization}

Cell immobilization was carried out as described in a previous study (Kourkoutas et al., 2005) with some modifications. In brief, $100 \mathrm{~g}$ of the immobilization support (strawberry, banana, or oat pieces cut in $1-\mathrm{cm}^{3}$ pieces) was introduced in 2-L cell cultures of $L b$. casei ATCC 393 or Lb. delbrueckii ssp. bulgaricus LB-12. The mixture was allowed to ferment at $37^{\circ} \mathrm{C}$ for $48 \mathrm{~h}$ without agitation. When immobilization was complete, the fermented liquid was decanted and the immobilized biocatalyst was washed twice with pasteurized milk.

\section{Probiotic Yogurt Production}

Yogurts were produced by inoculating pasteurized bovine milk $(100 \mathrm{~mL})$ with a yogurt culture consisting of $1 \mathrm{~g}$ (wet weight) of Lb. delbrueckii ssp. bulgaricus and
$1 \mathrm{~g}$ (wet weight) of Strep. salivarius ssp. thermophilus. Additional adjunct cultures of immobilized $L b$. casei ATCC 393 (10 g wet weight) or immobilized Lb. delbrueckii ssp. bulgaricus (10 g wet weight) on strawberry, banana, or oat pieces were added separately at 37 to $40^{\circ} \mathrm{C}$. For comparison reasons, probiotic yogurts using free cells ( $1 \mathrm{~g}$ of wet weight) of $L b$. casei ATCC 393 as adjunct culture were also produced. The initial cell counts for all cultures ( $L b$. casei ATCC 393, Lb. delbrueckii ssp. bulgaricus, and Strep. salivarius ssp. thermophilus) were $\sim 9 \log \mathrm{cfu} / \mathrm{g}$. Therefore, 8 types of yogurts were prepared in total: (1) probiotic yogurt containing immobilized Lb. casei ATCC 393 on strawberry pieces (y_LCSTR), (2) probiotic yogurt containing immobilized $L b$. casei ATCC 393 on banana pieces (y_LCBAN), (3) probiotic yogurt containing immobilized Lb. casei ATCC 393 on oat pieces (y_ LCOAT), (4) probiotic yogurt containing free $L b$. casei ATCC 393 (y_LCFREE), (5) yogurt containing immobilized Lb. delbrueckii ssp. bulgaricus on strawberry pieces (y_LBSTR), (6) yogurt containing immobilized $L b$. delbrueckii ssp. bulgaricus on banana pieces (y_LBBAN), (7) yogurt containing immobilized $L b$. delbrueckii ssp. bulgaricus on oat pieces (y_LBOAT), and (8) yogurt containing free Lb. delbrueckii ssp. bulgaricus (y_LBFREE).

All experiments were carried out in triplicate, and yogurts were stored at $4^{\circ} \mathrm{C}$ for $67 \mathrm{~d}$ after production. Samples from each treatment were collected at various intervals $(1,4,7,10,14,30$, and $67 \mathrm{~d})$ and subjected to microbiological and molecular analyses.

\section{pH Measurement}

During yogurt production, $\mathrm{pH}$ measurements were carried out using (pH-330i pH meter, WTW GmbH, Weilheim, Germany) pH meter.

\section{Microbial Enumeration}

Representative 10-g portions of duplicate immobilized cells or yogurt samples were blended with $90 \mathrm{~mL}$ of sterilized quarter-strength Ringers solution (SigmaAldrich, Gillingham, UK) and subjected to serial dilutions. Lactobacilli (gram-positive, catalase-negative) counts were determined on acidified MRS agar (Fluka) at $37^{\circ} \mathrm{C}$ for $48 \mathrm{~h}$ anaerobically (Anaerobic jar, Anerocult C, Merck, Darmstadt, Germany), whereas counts of Strep. salivarius ssp. thermophilus were determined on M17 agar (Fluka) at $37^{\circ} \mathrm{C}$ for $48 \mathrm{~h}$ aerobically.

\section{Identification of Lb. casei ATCC 393 and Lb. delbrueckii ssp. bulgaricus by Multiplex PCR}

To confirm the presence or absence of $L b$. casei ATCC 393 and Lb. delbrueckii ssp. bulgaricus in yogurt 
Table 1. Sequence and optimal amount of oligonucleotide primers used in this study

\begin{tabular}{llcl}
\hline Primer & Primer sequence $\left(5^{\prime} \rightarrow 3^{\prime}\right)$ & $\begin{array}{c}\text { Amount } \\
(\mathrm{pmol})\end{array}$ & Reference \\
\hline p78F & GGCGACCAAGGCAGCG & 10 & Karapetsas et al., 2010 \\
p156F & CTTCGGTTTCATCTTCC & 50 & Karapetsas et al., 2010 \\
p189R & GGCCAACTTTTTCCATA & 50 & Karapetsas et al., 2010 \\
p95F & CAGGTTGGTGTTACTC & 60 & Nikolaou et al., 2011 \\
p430F & CTGTTAAGGTGGCGACA & 20 & Nikolaou et al., 2011 \\
p169R & CTGAAAGCAAGTCTCT & 60 & Nikolaou et al., 2011 \\
p630R & TCAAGATGTAGACTTGG & 60 & Nikolaou et al., 2011 \\
Lac1F & AGCAGTAGGGAATCTTCCA & 10 & Walter et al., 2001 \\
Lac2R & ATTYCACCGCTACACATG & 10 & Walter et al., 2001 \\
\hline
\end{tabular}

samples, a methodology recently described by Sidira et al. (2010) and Saxami et al. (2012) was followed. Briefly, after growth of the cultures on MRS agar, the plates corresponding to all dilutions were washed with $1 \mathrm{~mL}$ of sterilized quarter-strength Ringers solution (Sigma-Aldrich) and then the cell suspension was subjected to molecular analysis based on multiplex PCR methodology (Karapetsas et al., 2010; Nikolaou et al., 2011). Genomic DNA from the lactobacilli suspensions was extracted using a DNeasy Tissue Kit (Qiagen, Hilden, Germany) according to the manufacturer's protocol. All multiplex PCR reactions were carried out in a total volume of $50 \mu \mathrm{L}$, containing $5 \mathrm{U}$ of Taq DNA polymerase (HyTest Ltd., Turku, Finland), a $400 \mu M$ concentration of each deoxynucleotide triphosphate (Promega, Southampton, UK), $1.5 \mathrm{mM} \mathrm{MgCl}$ (HyTest Ltd.), and $100 \mathrm{ng}$ of template DNA. A detailed description of all primers used, including amplicon size, optimal amount, and specificity, is presented in Tables 1 and 2. For PCR optimization, a positive (pure cultures of Lb. casei ATCC 393 or Lb. delbrueckii ssp. bulgaricus, respectively) and a negative control (yogurt prepared in the laboratory lacking Lb. casei ATCC 393 or Lb. delbrueckii ssp. bulgaricus, respectively) were also included in the assay. Amplification was carried out in a Thermal Cycler (Mastercycler Eppendorf, Hamburg, Germany) under the following conditions: for Lb. casei ATCC 393, $94^{\circ} \mathrm{C}(2 \mathrm{~min})$, followed by 25 cycles of $94^{\circ} \mathrm{C}(15 \mathrm{~s}), 51^{\circ} \mathrm{C}$ $(15 \mathrm{~s}), 72^{\circ} \mathrm{C}(30 \mathrm{~s})$, followed by a final extension step at $72^{\circ} \mathrm{C}$ (1 min); for $L b$. delbrueckii ssp. bulgaricus, $94^{\circ} \mathrm{C}(3$ min), followed by 30 cycles of $94^{\circ} \mathrm{C}(15 \mathrm{~s}), 58^{\circ} \mathrm{C}(15 \mathrm{~s})$, $72^{\circ} \mathrm{C}(1 \mathrm{~min})$, followed by a final extension step at $72^{\circ} \mathrm{C}$ (2 min). The PCR products were separated on $1.5 \%$ (wt/vol) agarose gels, visualized under UV illumination, and photographed with a digital camera (Gel Doc EQ System, BioRad, Segrate, Italy).

\section{Preliminary Sensory Evaluation}

Yogurts produced in the laboratory were compared with commercial plain yogurts of a similar type or to yogurts containing fruit pieces and cereals for their sensory characteristics. Samples of approximately $25 \mathrm{~g}$ were served in random order at room temperature. Sensory evaluation was conducted in triplicate by 12 tasters (6 laboratory members and 6 volunteers) using locally approved protocols. The panel was asked to give scores on a 0 to 5 scale $(0=$ unacceptable, $5=$ exceptional $)$ for attributes grouped into 5 categories: appearance, viscosity, taste, aroma, and overall quality. Panelists used water to clean their palates between samples and were unaware of the identity of the samples they tasted.

\section{Scanning Electron Microscopy}

The immobilization of $L b$. casei ATCC 393 and $L b$. delbrueckii ssp. bulgaricus cells on fruit and oat pieces was monitored by scanning electron microscopy. Pieces

Table 2. Amplicon size and specificity of the primer pairs used in this study

\begin{tabular}{lccc}
\hline & & \multicolumn{2}{c}{ Strain specificity } \\
\cline { 3 - 4 } Primer pair & $\begin{array}{c}\text { Amplicon } \\
\text { size (bp) }\end{array}$ & $\begin{array}{c}\text { Lactobacillus casei } \\
\text { ATCC 393 }\end{array}$ & $\begin{array}{c}\text { Lactobacillus delbrueckii } \\
\text { ssp. bulgaricus }\end{array}$ \\
\hline $\mathrm{p} 78 \mathrm{~F} / \mathrm{p} 189 \mathrm{R}$ & 144 & + & - \\
$\mathrm{p} 156 \mathrm{~F} / \mathrm{p} 189 \mathrm{R}$ & 67 & + & - \\
$\mathrm{p} 95 \mathrm{~F} / \mathrm{p} 169 \mathrm{R}$ & 107 & - & + \\
$\mathrm{p} 430 \mathrm{~F} / \mathrm{p} 630 \mathrm{R}$ & 235 & - & + \\
$\mathrm{p} 95 \mathrm{~F} / \mathrm{p} 630 \mathrm{R}$ & 569 & + & + \\
Lac1F/Lac1R & 340 & & + \\
\hline
\end{tabular}


(a)

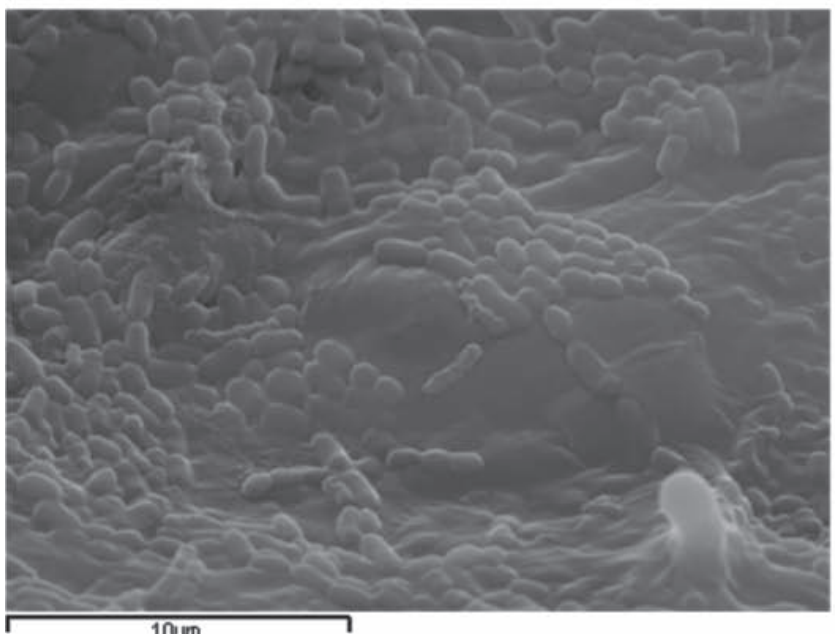

(b)

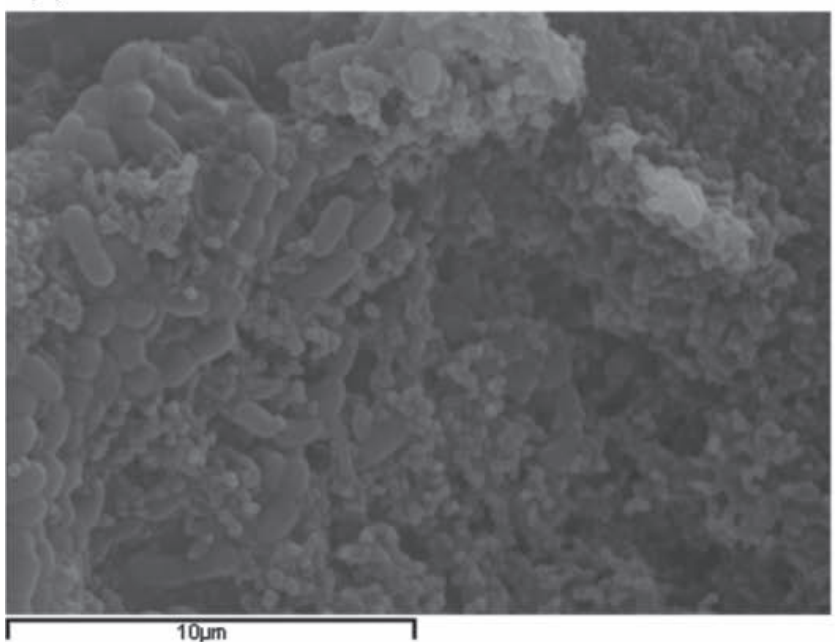

(c)

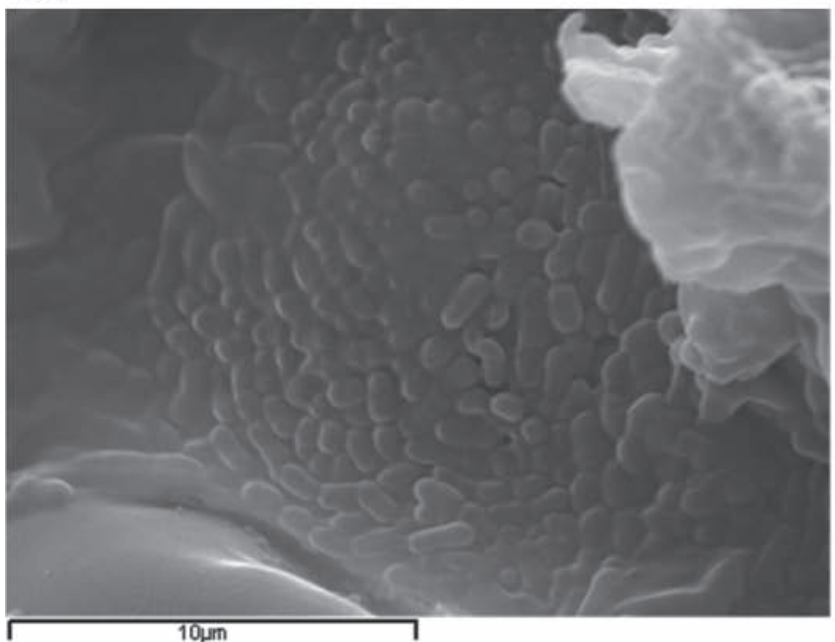

(d)

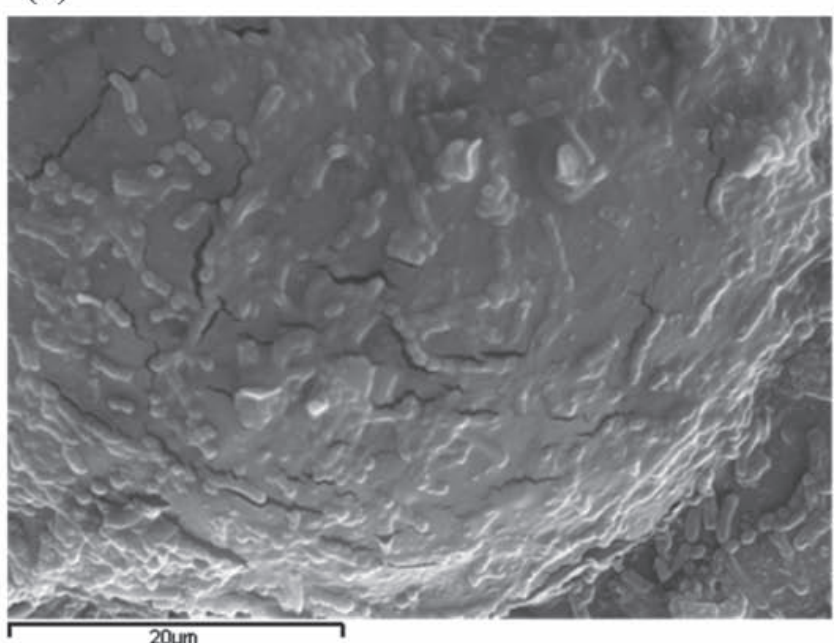

(e)

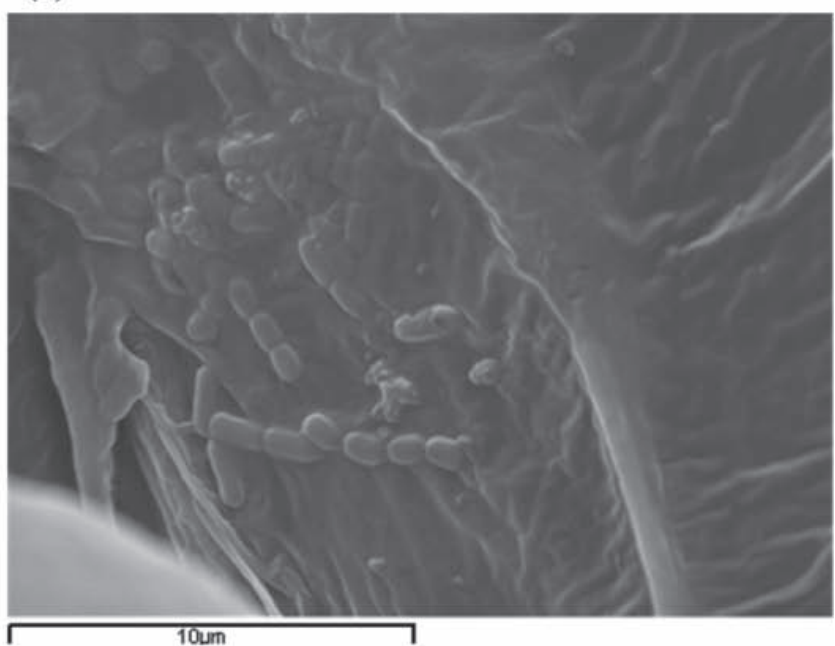

(f)

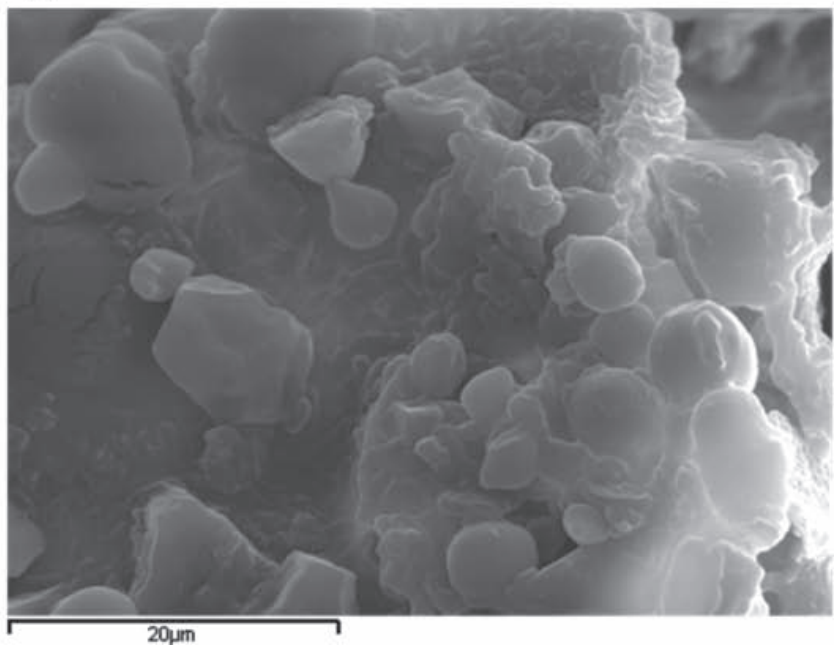

Figure 1. Electron micrographs showing immobilized cells of Lactobacillus casei ATCC 393 and Lactobacillus delbrueckii ssp. bulgaricus on fruit and oat pieces. Immobilized Lb. casei ATCC 393 on (a) strawberry pieces, (b) banana pieces, (c) oat pieces; immobilized Lb. delbrueckii ssp. bulgaricus on (d) strawberry pieces, (e) banana pieces, and (f) oat pieces. 
of the immobilized cells were washed with milk and dried overnight at $30^{\circ} \mathrm{C}$. The dried samples were coated with gold in a Balzers SCD 004 Sputter coater (BalTec/Leica Microsystems, Wetzlar, Germany) for 2 min and examined in a JSM-6300 scanning electron microscope (Jeol, Tokyo, Japan).

\section{Statistical Analysis}

All experiments were carried out in triplicate. Significance was established at $P<0.05$. Results were analyzed for statistical significance with ANOVA, and Duncan's multiple range test was used to determine significant differences among results; coefficients, ANOVA

(a)

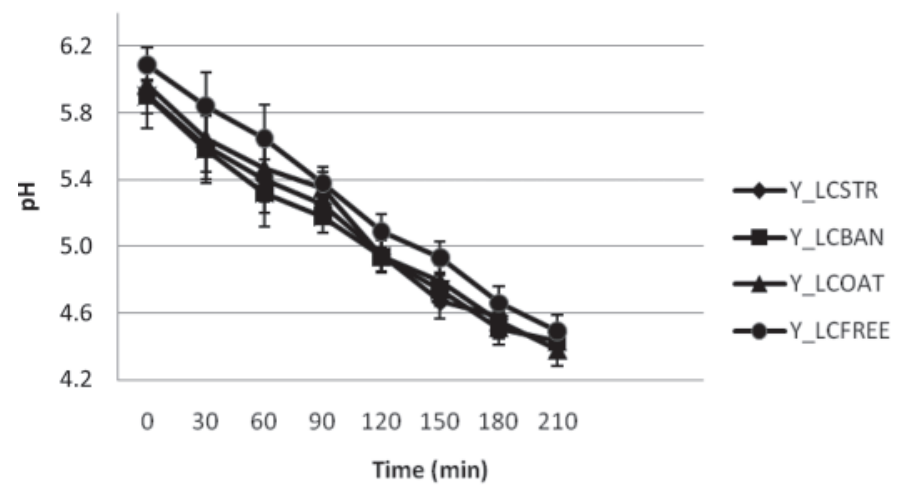

(b)

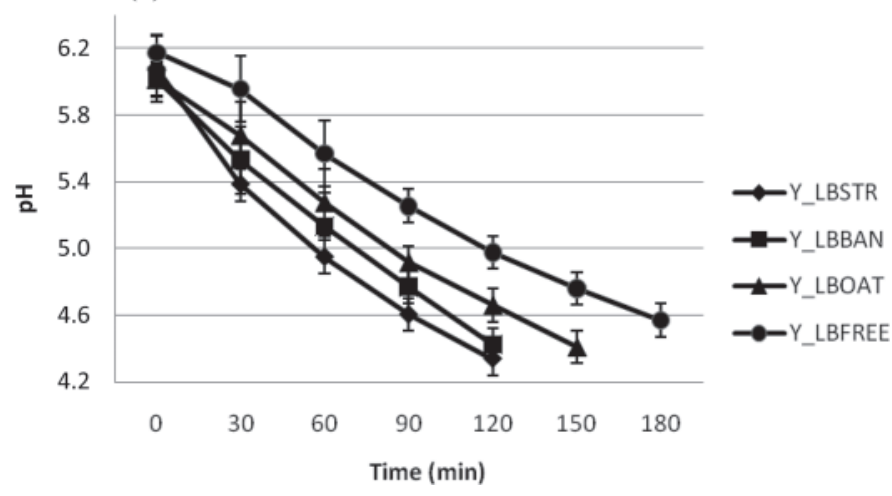

Figure 2. Fermentation kinetics during probiotic yogurt production using free and immobilized cells of (a) Lactobacillus casei ATCC 393 and (b) Lactobacillus delbrueckii ssp. bulgaricus on fruit and oat pieces. y_LCSTR $=$ probiotic yogurt containing immobilized $L b$. casei ATCC 393 on strawberry pieces, y_LCBAN = probiotic yogurt containing immobilized $L b$. casei ATCC 393 on banana pieces, y_LCOAT $=$ probiotic yogurt containing immobilized $L b$. casei ATCC 393 on oat pieces, and y_LCFREE = probiotic yogurt containing free $L b$. casei ATCC 393; y_LBSTR $=$ probiotic yogurt containing immobilized $L b$. delbrueckii ssp. bulgaricus on strawberry pieces, y_LBBAN = probiotic yogurt containing immobilized $L b$. delbrueckii ssp. bulgaricus on banana pieces, y_LBOAT = probiotic yogurt containing immobilized Lb. delbrueckii ssp. bulgaricus on oat pieces, and y_LBFREE $=$ probiotic yogurt containing free $L b$. delbrueckii ssp. bulgaricus. Error bars indicate standard deviations $(\mathrm{n}=3)$. tables and significance $(P<0.05)$ were computed using Statistica version 5.0 (StatSoft Inc., Tulsa, OK). Differences between means were evaluated using the Student's $t$-test (data were computed using the Excel 2007 software; Microsoft Corp., Redmond, WA).

\section{RESULTS}

\section{Cell Immobilization and Probiotic Yogurt Production}

The number of immobilized Lb. casei ATCC 393 or $L b$. delbrueckii ssp. bulgaricus cells ranged from 8 to $9 \mathrm{log} \mathrm{cfu} / \mathrm{g}$ in all cases. Cell immobilization was also studied by electron microscopy (Figure 1).

Free or immobilized cells of Lb. casei ATCC 393 were used as adjunct cultures in probiotic yogurts, and yogurts containing free or immobilized $L b$. delbrueckii ssp. bulgaricus were also produced for comparison. In all cases, milk coagulation was achieved by a yogurt culture consisting of Lb. delbrueckii ssp. bulgaricus and Strep. salivarius ssp. thermophilus. Fermentation kinetics are shown in Figure 2. Faster fermentation rates were observed in immobilized cells, as expected.

\section{Monitoring of Probiotic Cell Survival}

Lactobacilli counts in yogurt samples during refrigerated storage are presented in Figure 3. A significant reduction was observed $(P<0.05)$ only in yogurts containing free or immobilized $L b$. delbrueckii ssp. bulgaricus (samples y_LBSTR, y_LBBAN, y_LBOAT, and y_LBFREE).

After cell enumeration, the presence or absence of Lb. casei ATCC 393 and Lb. delbrueckii ssp. bulgaricus in Petri dishes corresponding to all dilutions was confirmed by multiplex PCR. The results demonstrated that both free and immobilized Lb. casei ATCC 393 were detected in probiotic yogurts at levels required to confer a probiotic effect $(\geq 6 \log \mathrm{cfu} / \mathrm{g})$ after $30 \mathrm{~d}$ of storage at $4{ }^{\circ} \mathrm{C}$ (Figure 4a), but not after $67 \mathrm{~d}$ of refrigerated storage (Figure 4b). In contrast, both free and immobilized $L b$. delbrueckii ssp. bulgaricus were detected in yogurts at levels $\geq 6 \mathrm{log} \mathrm{cfu} / \mathrm{g}$ only after $10 \mathrm{~d}$ of storage at $4^{\circ} \mathrm{C}$ (Figures 3 and 5 ). Cell viability decreased to lower levels ( $<6 \log \mathrm{cfu} / \mathrm{g}$ ) during further storage $(>10 \mathrm{~d})$ despite the protection provided by immobilization (Figure 3). Of note, the same results concerning the viability of Lb. delbrueckii ssp. bulgaricus were observed in probiotic yogurts containing both Lactobacillus strains (samples y_LCSTR, y_LCBAN, y_LCOAT, and y_LCFREE; data not shown). At 67 $\mathrm{d}$, extended spoilage was observed in all samples due to growth of yeasts and molds, which may have resulted in further decrease of bacterial viability (data not shown). 


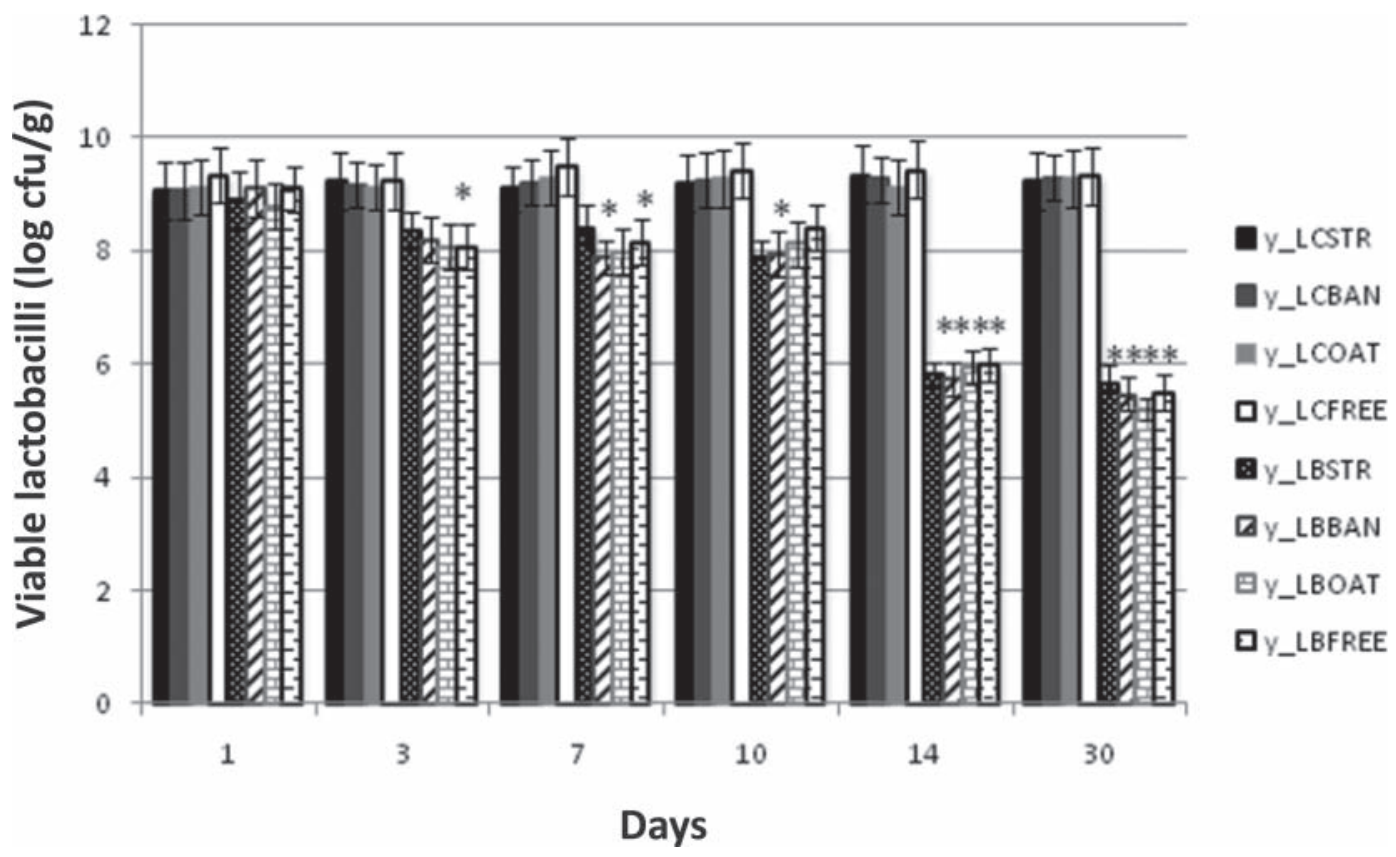

Figure 3. Lactobacilli counts in yogurt samples during refrigerated storage. On d 67, extended spoilage was observed and no lactobacilli were detected during the microbiological analysis. y_LCSTR = probiotic yogurt containing immobilized Lb. casei ATCC 393 on strawberry pieces, y_LCBAN = probiotic yogurt containing immobilized Lb. casei ATCC 393 on banana pieces, y_LCOAT = probiotic yogurt containing immobilized $L b$. casei ATCC 393 on oat pieces, and y_LCFREE = probiotic yogurt containing free $L b$. casei ATCC 393; y_LBSTR = probiotic yogurt containing immobilized $L b$. delbrueckii ssp. bulgaricus on strawberry pieces, y_LBBAN = probiotic yogurt containing immobilized $L b$. delbrueckii ssp. bulgaricus on banana pieces, y_LBOAT = probiotic yogurt containing immobilized Lb. delbrueckii ssp. bulgaricus on oat pieces, and y_LBFREE $=$ probiotic yogurt containing free $L b$. delbrueckii ssp. bulgaricus. Error bars indicate standard deviations $(\mathrm{n}=3)$. Significant differences were determined by Student's $t$-test $(* P<0.05$ vs. d 1$)$.

\section{Preliminary Sensory Evaluation}

The sensory characteristics of the novel products were compared with similar types of commercial yogurts. The preliminary sensory evaluation ascertained the fine taste and the overall high quality of the experimental yogurts containing immobilized $L b$. casei ATCC 393 or Lb. delbrueckii ssp. bulgaricus, although the tasters showed a preference $(P<0.05)$ for the commercial products (data not shown), probably because of small differences in laboratory-scale production compared with commercial production. Of note, no significant differences $(P>0.05)$ were observed between commercial yogurts with no fruits and yogurts containing free cells for all attributes except viscosity. All yogurts produced in the laboratory had lower $(P<0.05)$ values for viscosity, because no filtration was carried out during production. However, the new probiotic yogurts were approved and accepted by the panel (data not shown).

\section{DISCUSSION}

Probiotic starter cultures in food production should be designed to meet health-promoting claims and technological effectiveness, as well as economic feasibility criteria (Ammor and Mayo, 2007). Lactobacillus casei ATCC 393 has been proposed previously for the production of probiotic fermented milk and cheese because of its excellent technological properties (Kourkoutas et al., 2005, 2006), and the use of cell immobilization has shown significantly increased survival rates over the use of free cells during food manufacture and storage (Kourkoutas et al., 2005, 2006). Recently, the probiotic properties of free and immobilized Lb. casei ATCC 393 were assessed by documenting survival after transit through the GI tract, adhesion at the large intestine, and regulation of the intestinal microbial flora in rats (Sidira et al., 2010; Saxami et al., 2012). Although the probiotic properties of $L b$. delbrueckii ssp. bulgaricus are not fully characterized (Guarner et al., 2005; Mater et al., 2005; Guglielmotti et al., 2007), this strain is extensively used in yogurt production. Thus, the scope of the present study was to investigate the survival of free and immobilized $L b$. casei ATCC 393 on supports widely used in commercial products, such as strawberry, banana, and oat pieces, compared with free or immobilized $L b$. delbrueckii ssp. bulgaricus, which were used as controls. Studies reporting the survival of adjunct probiotic strains in food products in adequate levels for conferring the health benefits are scarce in the 
(a)
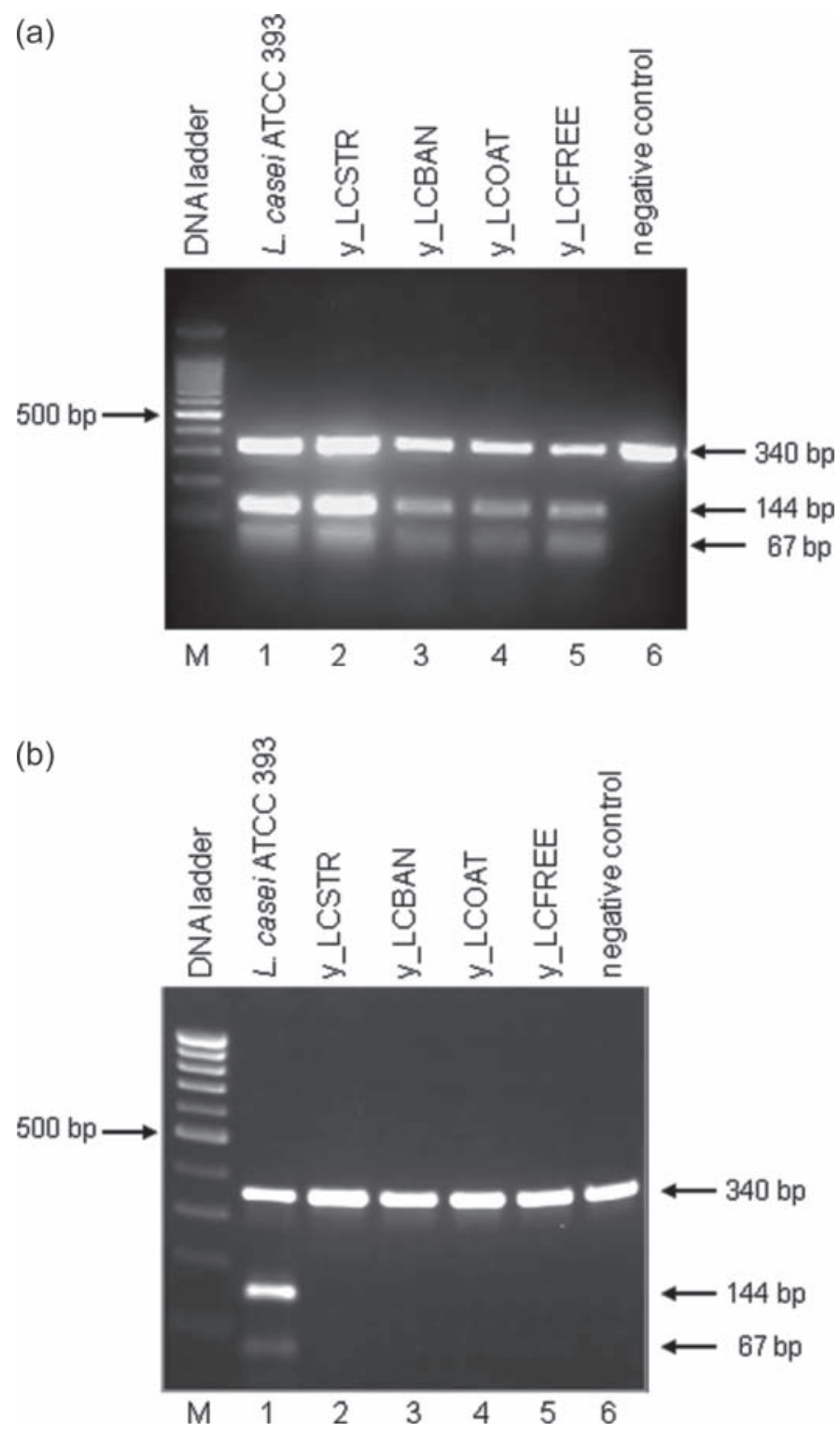

Figure 4. Molecular identification of Lactobacillus casei ATCC 393 in yogurts. After lactobacilli enumeration on de Man, Rogosa, and Sharpe agar plates, the presence or absence of Lb. casei ATCC 393 at levels $\geq 6 \log \mathrm{cfu} / \mathrm{g}$ in yogurts after (a) 30 and (b) $67 \mathrm{~d}$ of storage at $4^{\circ} \mathrm{C}$ was confirmed by strain-specific multiplex PCR. y_LCSTR $=$ probiotic yogurt containing immobilized Lb. casei ATCC 393 on strawberry pieces (lane 2), y_LCBAN = probiotic yogurt containing immobilized Lb. casei ATCC 393 on banana pieces (lane 3), y_LCOAT $=$ probiotic yogurt containing immobilized $L b$. casei ATCC 393 on oat pieces (lane 4), and y_LCFREE = probiotic yogurt containing free Lb. casei ATCC 393 (lane 5). For PCR optimization, a positive (pure culture of $L b$. casei ATCC 393; lane 1) and a negative control (yogurt prepared in the laboratory lacking $\mathrm{Lb}$. casei ATCC 393; lane 6) were also included. The PCR products of 67 and $144 \mathrm{bp}$ are unique to $L b$. casei ATCC 393, whereas the PCR product of 340 bp is universal for lactobacilli. literature because of the lack of an accurate, reliable, convenient, and sensitive method of identification.

The high survival rates of $L b$. casei ATCC 393 observed in the present study could be attributed to the acid-resistant nature of the strain (Kourkoutas et al., 2005; Sidira et al., 2010; Zhang et al., 2012). In contrast, the reduction in viable cell numbers of $L b$. delbrueckii ssp. bulgaricus was probably due to the high acid sensitivity of the strain (Dave and Shah, 1997). However, the fact that $L b$. delbrueckii ssp. bulgaricus cells may not be recoverable (although still viable) because of cold or acid-stress cannot be excluded. Similar results reporting survival of free and encapsulated probiotic cultures in yogurt after refrigerated storage for long periods have been published (Sultana et al., 2000; Vinderola et al., 2000; Picot and Lacroix, 2004; Capela et al., 2006; Maragkoudakis et al., 2006; Donkor et al., 2007), although a significant decline in viable counts was observed in many cases, resulting in levels $<6 \log \mathrm{cfu} / \mathrm{g}$ (Vinderola et al., 2000; Picot and Lacroix, 2004). However, in these studies, cell survival was based on assays unable to identify the probiotic among other LAB strains; hence, the probiotic characterization of the products was dubious. To the best of our knowledge, this is the first report concerning detection and identification of the adjunct probiotic strain at the required concentration for conferring a probiotic effect in yogurts after cold storage.

Production of probiotic foods containing viable probiotic strains at necessary levels for improving human health throughout their shelf-life is a technological challenge. Our data suggested that both free and immobilized $L b$. casei ATCC 393 cells survived for longer periods during refrigerated storage than required by the commercial sector at essential levels for providing the probiotic character $(\geq 6 \log \mathrm{cfu} / \mathrm{g})$, taking into account that the usual maximum shelf-life of yogurts is $25 \mathrm{~d}$. The higher survival rates of Lb. casei ATCC 393 compared with Lb. delbrueckii ssp. bulgaricus observed in this study could be attributed to possible differences in the acid-resistant nature of the 2 strains. Recently, the acid-resistant properties of $L b$. casei Zhang were investigated (Zhang et al., 2012; Wu et al., 2012a,b). An acid-resistant mutant of $L b$. casei Zhang, which showed a 318-fold higher survival rate during acid stress compared with the parental strain, was selected by adaptive evolution (Zhang et al., 2012). A comparison study of the 2 strains by an elegant proteomics analysis demonstrated that adaptation to low $\mathrm{pH}$ is associated with changes in critical regulatory cellular pathways, including DNA replication and protein synthesis ( $\mathrm{Wu}$ et al., 2012a). Moreover, specific physiological alterations of the acid-resistant mutant's cell membrane were recorded to maintain functionality in response to acid- 


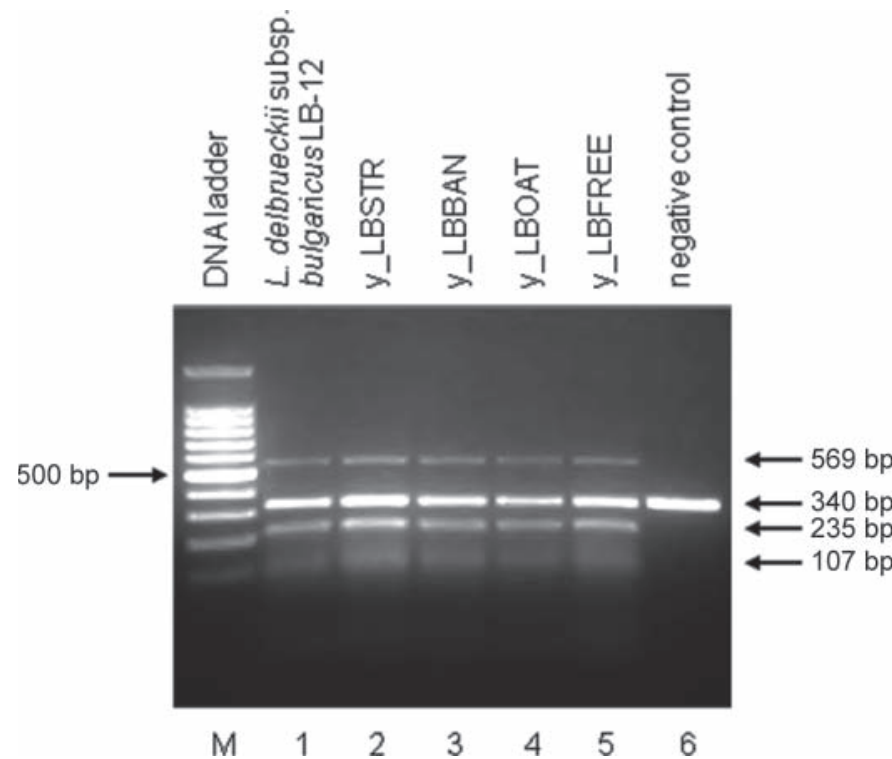

Figure 5. Molecular identification of Lactobacillus delbrueckii ssp. bulgaricus in yogurts. After lactobacilli enumeration on de Man, Rogosa, and Sharpe agar plates, the presence of Lb. delbrueckii ssp. bulgaricus at levels $\geq 6 \log \mathrm{cfu} / \mathrm{g}$ in yogurts after $10 \mathrm{~d}$ of storage at $4^{\circ} \mathrm{C}$ was confirmed by species-specific multiplex PCR. y_LBSTR = yogurt containing immobilized $L b$. delbrueckii ssp. bulgaricus on strawberry pieces (lane 2), y_LBBAN = yogurt containing immobilized $L b$. delbrueckii ssp. bulgaricus on banana pieces (lane 3), y_LBOAT = yogurt containing immobilized $L b$. delbrueckii ssp. bulgaricus on oat pieces (lane 4), and y_LBFREE = yogurt containing free $L b$. delbrueckii ssp. bulgaricus. For PCR optimization, a positive (pure culture of $L b$. delbrueckii ssp. bulgaricus; lane 1) and a negative control (yogurt prepared in the laboratory lacking $L$ b. delbrueckii ssp. bulgaricus; lane 6 ) were also included in the reaction. The PCR products of 107, 235, and $569 \mathrm{bp}$ are unique for Lb. delbrueckii ssp. bulgaricus, whereas the PCR product of $340 \mathrm{bp}$ is universal for lactobacilli.

stress, such as increased membrane fluidity and lower membrane permeability (Wu et al., 2012b). Distinct changes in both cytosolic proteins and membrane structure have also been demonstrated for Lb. bulgaricus CFL1 (Streit et al., 2008). Undoubtedly, it would be of great interest to investigate whether similar alterations apply to $L b$. casei ATCC 393 and Lb. delbrueckii ssp. bulgaricus during acid and cold adaptation.

Prebiotic supports, such as fruits and oat pieces, may constitute a useful vehicle for the transfer of probiotic cells in the GI tract (Sidira et al., 2010; Saxami et al., 2012). It is strongly believed that future clinical tests will ensure the beneficial effects of immobilized probiotics on prebiotic supports (unpublished data).

\section{CONCLUSIONS}

Both free and immobilized Lb. casei ATCC 393 were detected at the concentration necessary to confer a probiotic effect during refrigerated storage for longer periods than are required by the commercial sector, using a combined microbiological and molecular approach. Because consumption of probiotic products is associated with beneficial effects, future clinical trials will give more insight into the role of immobilized probiotic microorganisms on prebiotic supports, such as fruits and oat pieces, on promotion of human health.

\section{ACKNOWLEDGMENTS}

The research project was implemented within the framework of the Action "Supporting Postdoctoral Researchers" of the Operational Program "Education and Lifelong Learning" (Action's Beneficiary: General Secretariat for Research and Technology), and was cofinanced by the European Social Fund (ESF) and the Greek State.

\section{REFERENCES}

Ammor, M. S., and B. Mayo. 2007. Selection criteria for lactic acid bacteria to be used as functional starter cultures in dry sausage production: An update. Meat Sci. 76:138-146.

Boirivant, M., and W. Strober. 2007. The mechanism of action of probiotics. Curr. Opin. Gastroenterol. 23:679-692.

Bosnea, L., Y. Kourkoutas, N. Albantaki, C. Tzia, A. A. Koutinas, and M. Kanellaki. 2009. Functionality of freeze-dried Lb. casei cells immobilized on wheat grains. Lebenson. Wiss. Technol. 42:16961702 .

Boylston, T. D., C. G. Vinderola, H. B. Ghoddusi, and J. A. Reinheimer. 2004. Incorporation of bifidobacteria into cheeses: Challenges and rewards. Int. Dairy J. 19:315-387.

Capela, P., T. K. C. Hay, and N. P. Shah. 2006. Effect of cryoprotectants, prebiotics and microencapsulation on survival of probiotic organisms in yoghurt and freeze-dried yoghurt. Food Res. Int. 39:203-211.

Charalampopoulos, D., S. S. Pandiella, and C. Webb. 2003. Evaluation of the effect of malt, wheat and barley extracts on the viability of potentially probiotic lactic acid bacteria under acidic conditions. Int. J. Food Microbiol. 82:133-141.

Chen, K. N., M. J. Chen, J. R. Liu, C. W. Lin, and H. Y. Chiu. 2005. Optimization of incorporated prebiotics as coating materials for probiotic microencapsulation. J. Food Sci. 70:M260-M266.

Choi, S. S., Y. Kim, K. S. Han, S. You, S. Oh, and S. H. Kim. 2006. Effects of Lactobacillus strains on cancer cell proliferation and oxidative stress in vitro. Lett. Appl. Microbiol. 42:452-458.

Dave, R. I., and N. P. Shah. 1997. Viability of yoghurt and probiotic bacteria in yoghurts made from commercial starter cultures. Int. Dairy J. $7: 31-41$.

Dimitrellou, D., Y. Kourkoutas, A. A. Koutinas, and M. Kanellaki. 2009. Thermally-dried immobilized kefir on casein as starter culture in dried whey cheese production. Food Microbiol. 26:809820 .

Dimitrellou, D., K. Tsaousi, Y. Kourkoutas, P. Panas, M. Kanellaki, and A. A. Koutinas. 2008. Fermentation efficiency of thermallydried immobilized kefir on casein as starter culture. Process Biochem. 43:1323-1329.

Donkor, O. N., S. L. I. Nilmini, P. Stolic, T. Vasiljevic, and N. P. Shah. 2007. Survival and activity of selected probiotic organisms in set-type yoghurt during cold storage. Int. Dairy J. 17:657-665.

Fotiadis, C. I., N. Stoidis, G. Spyropoulos, and D. Zografos. 2008 Role of probiotics, prebiotics and synbiotics in chemoprevention for colorectal cancer. World J. Gastroenterol. 14:6453-6457.

Guarner, F., G. Perdigon, G. Corthier, S. Salminen, B. Koletzko, and L. Morelli. 2005. Should yoghurt cultures be considered probiotic? Br. J. Nutr. 93:783-786. 
Guglielmotti, D. M., M. B. Marcó, M. Golowczyc, J. A. Reinheimer, and A. del L. Quiberoni. 2007. Probiotic potential of Lactobacillus delbrueckii strains and their phage resistant mutants. Int. Dairy J. 17:916-925.

Karapetsas, A., E. Vavoulidis, A. Galanis, R. Sandaltzopoulos, and Y. Kourkoutas. 2010. Rapid detection and identification of probiotic Lactobacillus casei ATCC 393 by multiplex PCR. J. Mol. Microbiol. Biotechnol. 18:156-161.

Kopsahelis, N., P. Panas, Y. Kourkoutas, and A. A. Koutinas. 2007. Evaluation of thermally-dried immobilized cells of Lactobacillus delbrueckii ssp. bulgaricus on apple pieces as a potent starter culture. J. Agric. Food Chem. 55:9829-9836.

Kourkoutas, Y., L. Bosnea, S. Taboukos, C. Baras, D. Lambrou, and M. Kanellaki. 2006. Probiotic cheese production using Lactobacillus casei cells immobilized on fruit pieces. J. Dairy Sci. 89:14391451.

Kourkoutas, Y., V. Ksolis, M. Kallis, E. Bezirtzoglou, and M. Kanellaki. 2005. Lactobacillus casei immobilization on fruit pieces for probiotic additive, fermented milk and lactic acid production. Process Biochem. 40:411-416.

Li, X. Y., X. G. Chen, D. S. Cha, H. J. Park, and C. S. Liu. 2009. Microencapsulation of a probiotic bacteria with alginate-gelatin and its properties. J. Microencapsul. 26:315-324.

Maragkoudakis, P. A., C. Maris, P. Rojez, N. Manalis, F. Magkanari, G. Kalantzopoulos, and E. Tsakalidou. 2006. Production of traditional Greek yoghurt using Lactobacillus strains with probiotic potential as starter adjuncts. Int. Dairy J. 16:52-60.

Mater, D. D. G., L. Bretigny, O. Firmesse, M.-J. Flores, A. Mogenet, J.-L. Bresson, and G. Corthier. 2005. Streptococcus thermophilus and Lactobacillus delbrueckii ssp. bulgaricus survive gastrointestinal transit of healthy volunteers consuming yogurt. FEMS Microbiol. Lett. 250:185-187.

Mattila-Sandholm, T., P. Myllarinen, R. Crittenden, G. Mogensen, R. Fonden, and M. Saarela. 2002. Technological challenges for future probiotic foods. Int. Dairy J. 12:173-182.

Nikolaou, A., G. Saxami, Y. Kourkoutas, and A. Galanis. 2011. A new methodology for rapid detection of Lactobacillus delbrueckii ssp. bulgaricus based on multiplex PCR. J. Microbiol. Methods 84:362-364.

Oliveira, M. N., I. Sodini, F. Remeuf, J. P. Tissier, and G. Corrieu. 2002. Manufacture of fermented lactic beverages containing probiotic cultures. J. Food Sci. 67:2336-2341.

Picot, A., and C. Lacroix. 2004. Encapsulation of bifidobacteria in whey protein-based microcapsules and survival in simulated gastrointestinal conditions and in yoghurt. Int. Dairy J. 14:505-515.

Saulnier, D., J. Spinler, G. Gibson, and J. Versalovic. 2009. Mechanisms of probiosis and prebiosis: Considerations for enhanced func- tional foods. Curr. Opin. Biotechnol. 20:135-141. http://dx.doi. org/10.1016/j.copbio.2009.01.002.

Saxami, G., P. Ypsilantis, M. Sidira, C. Simopoulos, Y. Kourkoutas, and A. Galanis. 2012. Distinct adhesion of probiotic strain Lactobacillus casei ATCC 393 to rat intestinal mucosa. Anaerobe 18:417-420.

Sidira, M., A. Galanis, P. Ypsilantis, A. Karapetsas, Z. Progaki, C. Simopoulo, and Y. Kourkoutas. 2010. Effect of probiotic-fermented milk administration on gastrointestinal survival of Lactobacillus casei ATCC 393 and modulation of intestinal microbial flora. J. Mol. Microbiol. Biotechnol. 19:224-230.

Streit, F., J. Delettre, G. Corrieu, and C. Beal. 2008. Acid adaptation of Lactobacillus delbrueckii ssp. bulgaricus induces physiological responses at membrane and cytosolic levels that improves cryotolerance. J. Appl. Microbiol. 105:1071-1080.

Sultana, K., G. Godward, N. Reynolds, R. Arumugaswamy, P. Peiris, and K. Kailasapathy. 2000. Encapsulation of probiotic bacteria with alginate-starch and evaluation of survival in simulated gastrointestinal conditions and in yoghurt. Int. J. Food Microbiol. 62:47-55.

Vinderola, C. G., N. Bailo, and J. Reinheimer. 2000. Survival of probiotic microflora in Argentinian yoghurts during refrigerated storage. Food Res. Int. 33:97-102.

Vinderola, C. G., G. A. Costa, S. Regenhardt, and J. A. Reinheimer. 2002. Influence of compounds associated with fermented dairy products on the growth of lactic acid starter and probiotic bacteria. Int. Dairy J. 12:579-589.

Walter, J., C. Hertel, G. W. Tannock, C. M. Lis, K. Munro, and W. P. Hammes. 2001. Detection of Lactobacillus, Pediococcus, Leuconostoc, and Weissella species in human feces by using group-specific PCR primers and denaturing gradient gel electrophoresis. Appl. Environ. Microbiol. 67:2578-2585.

Wu, C., J. Zhang, W. Chen, M. Wang, G. Du, and J. Chen. 2012a. A combined physiological and proteomic approach to reveal lactic-acid-induced alterations in Lactobacillus casei Zhang and its mutant with enhanced lactic acid tolerance. Appl. Microbiol. Biotechnol. 93:707-722

Wu, C., J. Zhang, M. Wang, G. Du, and J. Chen. 2012b. Lactobacillus casei combats acid stress by maintaining cell membrane functionality. J. Ind. Microbiol. Biotechnol. 39:1031-1039.

Zhang, J., C. Wu, G. Du, and J. Chen. 2012. Enhanced acid tolerance in Lactobacillus casei by adaptive evolution and compared stress response during acid stress. Biotechnol. Bioproc. Eng. 17:283289 